\title{
PENGATURAN PENGANGKATAN PERANGKAT DESA DI KABUPATEN BLITAR
}

\author{
Weppy Susetiyo, Erwin Widhiandono, Anik Iftitah;
}

Fakultas Hukum Universitas Islam Balitar; Jl. Majapahit No.2-4, Kota Blitar, Jawa Timur;

E-mail:weppy_s@yahoo.co.id,erwinwidhiandono@yaoo.co.id, geest_willdaad@yahoo.com

\begin{abstract}
This research departs from the subject matter of the arrangement of appointment of village officials in Blitar Regency after the expulsion of the domicile requirements of prospective village officials by the Constitutional Court of the Republic of Indonesia (Article 50 Paragraph 1 letter c) of Law Number 6 of 2014 concerning Villages) because it proved unconstitutional. To answer questions, it is used for normative legal research, draw conclusions about disharmony in the arrangement of appointment of village officials, and arrangements for the appointment of village officials in Kab. Blitar contains a substance that is not legal certainty.
\end{abstract}

Keywords: Arrangement, Appointment of Village Devices, Blitar.

\section{LATAR BELAKANG}

Desa merupakan unsur terkecil pemerintahan daerah yang berperan penting dalam menyukseskan pembangunan nasional. Mempertimbangkan hal tersebut, diberlakukanlah Undang-Undang Nomor 6 Tahun 2014 tentang Desa (UU Desa) antara lain guna membentuk Pemerintahan Desa yang profesional, efisien dan efektif, terbuka, serta bertanggung jawab; meningkatkan pelayanan publik bagi warga masyarakat Desa guna mempercepat perwujudan kesejahteraan umum; memajukan perekonomian masyarakat Desa serta mengatasi kesenjangan pembangunan nasional; dan memperkuat masyarakat Desa sebagai subjek pembangunan.

Berhasil tidaknya eksistensi desa sebagai subjek pembangunan dalam kerangka menyukseskan pembangunan nasional, sangat erat kaitannya dengan kualitas sumber daya manusia (SDM) perangkat desanya. Perangkat Desa sebagai unsur penyelenggara Pemerintahan Desa, ${ }^{1}$ bertugas membantu Kepala Desa dalam melaksanakan tugas dan wewenang Kepala Desa. ${ }^{2}$ Perangkat Desa berperan membantu kepala desa dalam melaksanakan tugas menyelenggarakan pemerintahan desa, melaksanakan pembangunan desa, pembinaan, dan pemberdayaan masyarakat desa.

Pengaturan sebagai acuan perilaku manusia dalam masyarakatnya, guna terwujudnya tatanan kehidupan bermasyarakat yang tertib dan terintegrasi tinggi, ${ }^{3}$ merupakan substance rule of the law dalam Teori Legal Sistem Lawrence M. Friedmann. Pengaturan pemilihan dan pengangkatan perangkat desa seharusnya tidak perlu dibuat

\footnotetext{
1 Pasal 1 angka 3 Undang-Undang Nomor 6 Tahun 2014 tentang Desa.

2 Pasal 49, Ibid.

${ }^{3}$ Prof. Soetandyo Wignjosoebroto, "Hukum yang Tak Kunjung Tegak: Apa yang Salah dengan Kerja Penegakan Hukum di Negeri Ini?" dalam Dinal Fedrian dkk, Dialektika Pembaharuan Sistem Hukum Indonesia, Jakarta: Komisi Yudisial Republik Indonesia, 2012, h. 5 .
} 
rumit dan cenderung mempersulit orang yang ingin memberikan kontribusinya kepada daerah tersebut. Sebagai salah satu bukti adanya pengaturan pemilihan dan pengangkatan perangkat desa yang dianggap mempersulit, yakni adanya ketentuan Pasal 50 Ayat 1 huruf c UU Desa yang menyatakan Perangkat Desa diangkat dari warga Desa yang memenuhi persyaratan terdaftar sebagai penduduk dan bertempat tinggal di Desa setempat paling kurang 1 (satu) tahun sebelum pendaftaran.

Pengaturan tersebut memangkas hak banyak penduduk yang ingin berkarya menjadi perangkat desa, melanggar hak konstitusional warga negara untuk mendapatkan kemudahan dan perlakuan khusus untuk memperoleh kesempatan dan manfaat yang sama guna mencapai persamaan dan keadilan sebagai perangkat desa, hak untuk memperoleh kesempatan yang sama dalam pemerintahan, hak untuk bekerja dengan perlakuan yang adil sebagai perangkat desa, hak atas pengakuan, jaminan, perlindungan, dan kepastian hukum yang adil serta perlakuan yang sama di hadapan hukum, ${ }^{4}$ sehingga pada tanggal 23 Agustus 2016 Mahkamah Konstitusi menyatakan bahwa ketentuan tersebut bertentangan dengan Undang-Undang Dasar Negara Republik Indonesia dan tidak memiliki kekuatan hukum mengikat.

Bagaimana pengaturan pemilihan dan pengangkatan perangkat desa di daerah, khususnya di Kabupaten Blitar pasca penganuliran pasal syarat domisili calon perangkat desa tersebut di atas, menjadi urgen untuk diteliti, mengingat dan mempertimbangkan peranan Perangkat Desa sangat penting guna kesuksesan tidaknya penyelenggaraan pemerintahan desa dalam kerangka pembangunan nasional.

\section{TINJAUAN PUSTAKA}

\subsection{Pengertian Perangkat Desa}

Pemerintahan desa merupakan unit terdepan (ujung tombak) dalam pelayanan kepada masyarakat serta tombak strategis untuk keberhasilan semua program. ${ }^{5}$ Mengapa? Karena kompetensi sumber daya manusia (SDM) di pemerintahan desalah penentu perencanan anggaran desa agar berorientasi pada pengembangan potensi desa menuju kemandirian, penentu sejalan tidaknya implementasi penggunaan anggaran dengan perencanaan. ${ }^{6}$

\footnotetext{
4 Putusan Mahkamah Konstitusi Nomor 128/PUU-XIII/ 2015 tentang Pengujian UndangUndang Nomor 6 Tahun 2014 tentang Desa terhadap Undang-Undang Dasar Negara Republik Indonesia Tahun 1945, 23 Agustus 2016.

${ }^{5}$ Nur'aini Muslim dan Irwan Nasution, "Kinerja Aparat Desa dalam Penyelenggaraan Pemerintahan di desa Pantai Labu Pekan", Jurnal Ilmu Pemerintahan dan Sosial Politik UMA, 2 (2) (2014), h. 100.

${ }_{6}$ Pemahaman peneliti setelah membaca Agus Kusnadi, "Perkembangan Politik Hukum Pemerintahan Desa Menurut Undang-Undang Nomor 32 Tahun 2004 tentang Pemerintahan Daerah dan Undang-Undang Nomor 6 Tahun 2014 tentang Desa", Padjadjaran Jurnal Ilmu Hukum, Volume 2 Nomor 3 Tahun 2015, h. 578.
} 
Pemerintahan Desa terdiri dari Kepala Desa dan Perangkat Desa. Perangkat Desa adalah unsur staf yang membantu kepala Desa dalam penyusunan kebijakan dan koordinasi yang diwadahi dalam sekretariat Desa, dan unsur pendukung tugas kepala Desa dalam pelaksanaan kebijakan yang diwadahi dalam bentuk pelaksana teknis dan unsur kewilayahan7. Agar semakin gamblang, perhatikan Bagan I. Bagan Susunan Organisasi Pemerintah Desa.

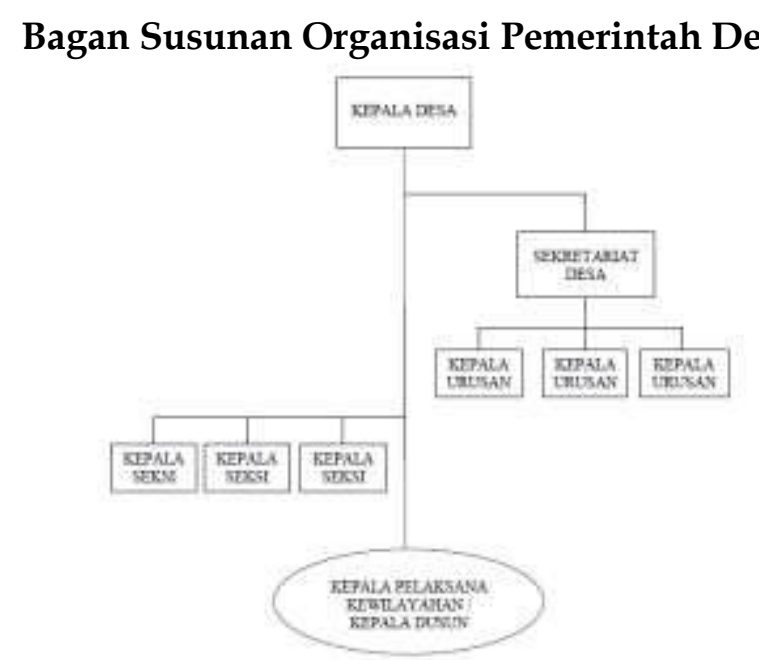

Sumber: Data Sekunder, 2018.

Dari Bagan I. Bagan Susunan Organisasi Pemerintah Desa, dapat jelas kita ketahui bahwa perangkat Desa sebagai unsur pemerintah desa, terdiri dari Sekretaris Desa (Sekdes) dan Perangkat Desa lainnya yang merupakan aparatur pemerintah desa di bawah naungan Kepala Desa (Kades). Adapun perangkat desa lainnya jumlah dan penyebutannya disesuaikan dengan kebutuhan dan kondisi sosial budaya masyarakat setempat yang biasa dikenal dengan sebutan Kepala Urusan (Kaur)/Kepala Seksi (Kasi) dan unsur kewilayahan/Kepala Dusun (Kasun) yang ada di setiap pemerintahan desa. ${ }^{9}$

Sesuai rumusan Pasal 1 angka 3 UU Desa, kedudukan Perangkat Desa adalah 'pembantu' bagi Kepala Desa dalam menjalankan fungsi pemerintahan. Dalam sistem ketatanegaraan Indonesia, kedudukan 'pembantu' juga dilekatkan kepada Wakil Presiden dan menteri-menteri. Secara yuridis normatif, pemahaman mengenai Perangkat Desa dapat diketahui dari Pasal 25, 48-49, 51-53 UU Desa.

\footnotetext{
7 Pasal 1 angka 5 Peraturan Menteri Dalam Negeri Republik Indonesia Nomor 67 Tahun 2017 tentang Perubahan Atas Peraturan Menteri Dalam Negeri Nomor 83 Tahun 2015 tentang Pengangkatan dan Pemberhentian Perangkat Desa.

8 Lampiran Peraturan Menteri Dalam Negeri Republik Indonesia Nomor 84 Tahun 2015 tentang Susunan Organisasi dan Tata Kerja Pemerintah Desa.

${ }^{9}$ Salman Alfarezi, Pengangkatan Perangkat Desa dalam Pandangan Hukum Islam dan Hukum Positif (Studi di Pekon Negeriagung, Kec. Talang Padang Kab. Tanggamus), Skripsi, Tidak Diterbitkan, Fakultas Ilmu Komunikasi, Universitas Harapan Jaya: Bandung.
} 


\subsection{Pengangkatan Perangkat Desa}

Pengangkatan dalam jabatan adalah pengangkatan kepada pegawai tetap atau pegawai negeri sipil pada jabatan-jabatan yang lebih tinggi. Pengangkatan dalam jabatan dalam suatu organisasi harus ada penilaian perestasi kerja pegawai dan mempuyai prestasi baik dapan diberikan penghargaan dengan mempertimbangkan prinsip profesionalisme sesuai dengan kompetensi, potensi kerja, dan jenjang pangkat yang ditetapkan untuk jabatan itu. ${ }^{10}$

Pasal 49 UU Desa telah menyebutkan bahwa Perangkat Desa diangkat oleh Kepala Desa. Dalam proses pengangkatan itu, Kepala Desa harus mempertimbangkan syaratsyarat yang sudah ditentukan UU Desa. Kepala Desa juga harus berkonsultasi dengan camat sebelum membuat keputusan pengangkatan. Dalam UU Desa, rumusan mengenai persyaratan Perangkat Desa diatur dalam Pasal 50, sedangkan pemberhentiannya diatur dalam Pasal 53.

Perangkat Desa sebagai unsur penyelenggara Pemerintahan Desa diangkat dari warga Desa yang memenuhi persyaratan: ${ }^{11}$

a. berpendidikan paling rendah sekolah menengah umum atau yang sederajat;

b. berusia 20 (dua puluh) tahun sampai dengan 42 (empat puluh dua) tahun;

c. terdaftar sebagai penduduk Desa dan bertempat tinggal di Desa paling kurang 1 (satu) tahun sebelum pendaftaran; dan (sebelum Putusan Mahkamah Konstitusi Nomor 128/PUU-XIII/ 2015 tentang Pengujian Undang-Undang Nomor 6 Tahun 2014 tentang Desa terhadap Undang-Undang Dasar Negara Republik Indonesia Tahun 1945, 23 Agustus 2016).

Perangkat Desa diangkat oleh kepala Desa dari warga Desa yang telah memenuhi persyaratan umum dan khusus. Mengingat tata peraturan perundang-undangan di Indonesia, ${ }^{12}$ persyaratan umum dan khusus calon perangkat desa lebih lanjut diatur dalam Pasal 2 dan 3 oleh Peraturan Menteri Dalam Negeri Republik Indonesia Nomor 67 Tahun 2017 tentang Perubahan Atas Peraturan Menteri Dalam Negeri Nomor 83 Tahun 2015 tentang Pengangkatan dan Pemberhentian Perangkat Desa, yaitu sebagai berikut:

1). Persyaratan umum calon perangkat desa yaitu:

a. berpendidikan paling rendah sekolah menengah umum atau yang sederajat;

b. berusia 20 (dua puluh) tahun sampai dengan 42 (empat puluh dua) tahun;

c. dihapus;

10 Soeno S.H., Ilmu Negara, Yogyakarta: Libeti, 2005, h. 146.

11 Pasal 50 UU Desa.

12 Ingat tata peraturan perundang-undangan berdasakan ketentuan Undang-Undang Nomor 12 Tahun 2011 tentang Pembentukan Peraturan Perundang-Undangan yaitu :

1. Undang-Undang Dasar Negara Republik Indonesia Tahun 1945;

2. Ketetapan Majelis Permusyawaratan Rakyat;

3. Undang-Undang/Peraturan Pemerintah Pengganti Undang-Undang;

4. Peraturan Presiden;

5. Peraturan Daerah Provinsi;

6. Peraturan Daerah Kabupaten/Kota. 
d. memenuhi kelengkapan persyaratan administrasi, yang terdiri atas:

a. Kartu Tanda Penduduk; dan/atau

b. Surat keterangan tanda penduduk;

c. surat pernyataan bertakwa kepada Tuhan Yang Maha Esa yang dibuat oleh yang bersangkutan di atas kertas bermaterai;

d. surat pernyataan memegang teguh dan mengamalkan Pancasila, UndangUndang Dasar Negara Republik Indonesia Tahun 1945, mempertahankan dan memelihara keutuhan Negara Kesatuan Republik Indonesia dan Bhinneka Tunggal Ika, yang dibuat oleh yang bersangkutan diatas kertas segel atau bermaterai cukup;

e. ijazah pendidikan dari tingkat dasar sampai dengan ijazah terakhir yang dilegalisasi oleh pejabat berwenang atau surat pernyataan dari pejabat yang berwenang;

f. akte kelahiran atau surat keterangan kenal lahir;

g. surat keterangan berbadan sehat dari puskesmas atau aparat kesehatan yang berwenang; dan

h. surat permohonan menjadi perangkat Desa yang dibuat oleh yang bersangkutan di atas kertas segel atau bermaterai cukup bagi perangkat Desa yang diproses melalui penjaringan dan penyaringan.

2). Persyaratan khusus calon perangkat desa yang dimaksud yaitu persyaratan yang bersifat khusus dengan memperhatikan hak asal usul dan nilai sosial budaya masyarakat setempat dan syarat lainnya.

Perangkat Desa yang telah diangkat dan ditetapkan oleh kepala desa, akan memperoleh penghasilan tetap setiap bulan, yang bersumber dari dana perimbangan dalam Anggaran Pendapatan dan Belanja Negara yang diterima oleh Kabupaten/Kota dan ditetapkan dalam Anggaran Pendapatan dan Belanja Daerah Kabupaten/Kota, menerima tunjangan yang bersumber dari Anggaran Pendapatan dan Belanja Desa, dan memperoleh jaminan kesehatan dan dapat memperoleh penerimaan lainnya yang sah. ${ }^{13}$ Di dalam Peraturan Pemerintah Nomor 43 Tahun 2014 tentang Peraturan Pelaksanaan Undang-Undang Nomor 6 Tahun 2014 tentang Desa diatur dalam Bagian Kedua dengan nomenklatur Perangkat Desa.

13 Pasal 66 UU Desa. 


\section{METODE PENELITIAN}

\subsection{Diagram Alir Penelitian}

Tahapan proses yang akan dilakukan dalam penelitian ini digambarkan dalam diagram alir Bagan II.

Bagan II. Diagram Alir Penelitian

Pengaturan Pengangkatan Perangkat Desa di Kabupaten Blitar

\section{Tahap Awal Penelitian}

- Menentukan Topik

- Menentukan Rumusan Permasalahan

- Menentukan Tujuan dan Ruang Lingkup Penelitian

Tahap Pengolahan dan Analisis Data

- Jenis Penelitian

- Pendekatan Penelitian

- Pengumpulan Bahan Hukum (Library Research)

- Pengolahan Bahan Hukum

- Analisis Bahan Hukum

Tahap Akhir

- Penyusunan Laporan

- Seminar Hasil Penelitian

- Publikasi Ilmiah (Jurnal SUPREMASI UNISBA, Prosiding Ilmu

Hukum serta Buku Ajar dalam Mata Kuliah Hukum Administrasi

Negara dan Ilmu Perundang-Undangan)

\subsection{Jenis Penelitian}

\section{Sumber: Data Sekunder yang Diolah, 2018}

Penelitian ini berangkat dari pokok persoalan mengenai pengaturan pengangkatan perangkat desa di Kabupaten Blitar pasca penganuliran syarat domisili calon perangkat desa oleh Mahkamah Konstitusi Republik Indonesia. Untuk menjawab permasalahan yang telah dirumuskan dalam penelitian ini, digunakan penelitian hukum normatif.

Penelitian hukum normatif di dalam literatur hukum asing biasa disebut dengan legal research dan tanpa tambahan makna lain, menurut sebagian penstudi hukum dikatakan sebagai penelitian hukum yang murni (the pure legal research). ${ }^{14}$ Penelitian hukum normatif (normative law research) menggunakan studi kasus hukum normatif

${ }_{14}$ Depri Liber Sonata, "Metode Penelitian Hukum Normatif dan Empiris: Karakteristik Khas dari Metode Meneliti Hukum", Fiat Justisia Jurnal Ilmu Hukum, Volume 8 No. 1, Januari-Maret 2014, h. 28. 
berupa produk perilaku hukum. ${ }^{15}$ Dalam konteks penelitian ini, pokok kajiannya adalah hukum positif di Kabupaten Blitar mengenai pengangkatan perangkat desa.

\subsection{Sumber Data}

Dalam penelitian pada umumnya dibedakan antara data yang diperoleh secara langsung dari masyarakat dan dari bahan-bahan pustaka. Yang diperoleh langsung dari masyarakat dinamakan data primer (atau data dasar), sedangkan yang diperoleh dari bahan-bahan pustaka lazimnya dinamakan data sekunder. ${ }^{16}$

Sesuai dengan tipe penelitian yuridis normatif maka data yang dikumpulkan adalah data sekunder. Pengumpulan data sekunder dimaksudkan sebagai upaya mendapatkan landasan teoritis yakni dengan mempelajari peraturan-peraturan, dokumen-dokumen dan buku-buku yang ada kaitannya dengan masalah ini, serta pendapat para sarjana (doktrin).

Data sekunder di bidang hukum yang digunakan dalam penelitian ini mencakup tiga bagian yaitu:

a. Bahan Hukum Primer yaitu bahan-bahan hukum yang mengikat, terdiri dari:

1) Undang-Undang Nomor 6 Tahun 2014 tentang Desa

2) Putusan Mahkamah Konstitusi Nomor 128/PUU-XIII/2015 tentang Pengujian Undang-Undang Nomor 6 Tahun 2014 tentang Desa terhadap Undang-Undang Dasar Negara Republik Indonesia Tahun 1945, 23 Agustus 2016.

3) Undang-Undang Nomor 12 Tahun 2011 tentang Pembentukan Peraturan Perundang-Undangan

4) Peraturan Menteri Dalam Negeri Republik Indonesia Nomor 67 Tahun 2017 tentang Perubahan Atas Peraturan Menteri Dalam Negeri Nomor 83 Tahun 2015 tentang Pengangkatan dan Pemberhentian Perangkat Desa.

5) Peraturan Menteri Dalam Negeri Republik Indonesia Nomor 84 Tahun 2015 tentang Susunan Organisasi dan Tata Kerja Pemerintah Desa

6) Peraturan Bupati Blitar Nomor 9 Tahun 2017 tentang Pedoman Pengangkatan dan Pemberhentian Perangkat Desa

b. Bahan Hukum Sekunder adalah bahan hukum yang terdiri atas buku-buku teks yang ditulis para ahli hukum yang berpengaruh, jurnal-jurnal hukum, pendapat para sarjana, kasus-kasus hukum, yurispudensi, dan hasil-hasil simposium mutakhir yang berkaitan dengan penelitian. ${ }^{17}$

${ }^{15}$ R.A. Granita Ramadhani, Analisa Aspek Metodologi, FH UI, 2009, h. 57.

16 Soerjono Soekanto dan Sri Mamudji, Penelitian Hukum Normatif, Suatu Tinjauan Singkat, Jakarta: Raja Grafindo Persada, 2011, h. 12.

17 Johnny Ibrahim, Teori dan Metode Penelitian Hukum Normatif, Cet. 4, Malang: Bayumedia Publishing, 2011, h. 296. 
c. Bahan hukum tersier adalah bahan hukum yang memberikan petunjuk atau penjelasan terhadap bahan hukum primer dan bahan hukum sekunder seperti kamu hukum, ecyclopedia, dan lain-lain.18

\subsection{Metode Pengumpulan Data}

Metode pengumpulan data dalam penelitian ini dilakukan dengan studi pustaka, yaitu suatu cara pengumpulan data dengan melakukan penelusuran dan menelaah bahan pustaka (literatur, hasil penelitian, majalah ilmiah, buletin ilmiah, jurnal ilmiah dsb).

\subsection{Metode Penyajian Data}

Hasil penelitian disajikan dalam bentuk uraian-uraian yang tersusun secara sistematis, artinya data sekunder yang diperoleh akan dihubungkan satu dengan yang lain disesuaikan dengan permasalahan yang diteliti, sehingga secara keseluruhan merupakan satu kesatuan yang utuh sesuai dengan kebutuhan penelitian.

\section{PENGATURAN PENGANGKATAN PERANGKAT DESA DI KABUPATEN BLITAR} Pasca Putusan MK No. 128/PUU-XIII/2015: Antara Visi Kemajuan dan Primordialisme

Pengangkatan perangkat desa secara demokratis menjanjikan terwujudnya pemerintahan desa yang kuat, maju, mandiri dan demokratis. ${ }^{19}$ Pengaturan perangkat desa di Indonesia, dapat kita pahami dengan memahami piramida ${ }^{20}$ substansi hukumnya, seperti tergambar pada Bagan III.

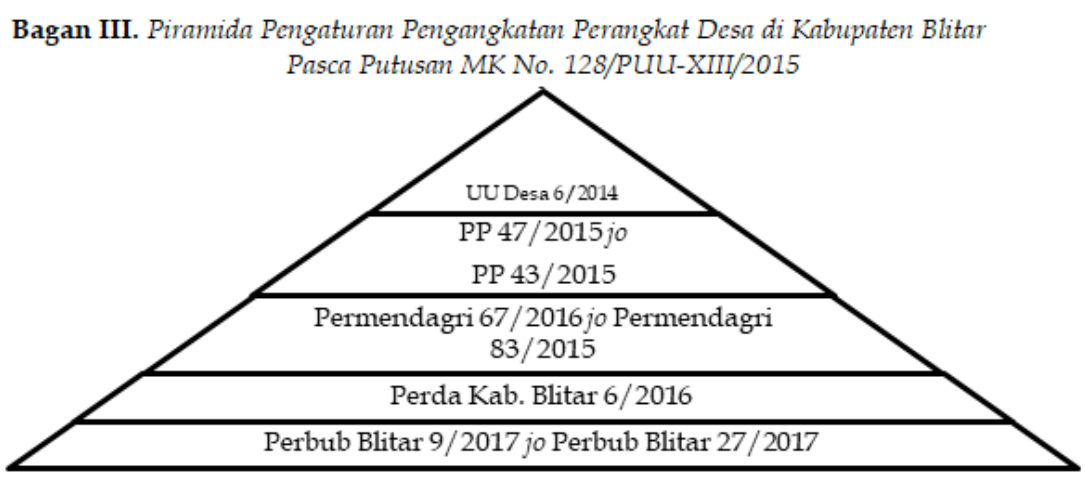

Sumber: Anik Iftitah, 2019

\section{Ibid.}

19 Lihat Fadhilah Lestari, "Analisis Putusan Mahkamah Konstitusi Nomor 128/PUUXIII/2015 terhadap Penghapusan Domisili Calon Kepala Desa dalam Pemilihan Kepala Desa", Tesis, Pascasarjana FH-UII, 2018, h.2.

20 Ingat Stufentheorie (pandangan sistem hukum sebagai bentuk piramid). Hukum membentangkan dalam proses yang bertahap, dari norma yang paling tinggi, yang paling abstrak, pemberian norma-norma umum dan murni, kepada yang terendah, yang secara lengkap diindividualisasikan, konkret dan eksekutif. Antara dua kutub ini tiap norma tidak hanya memberi hukum, tetapi juga melaksanakannya, dan oleh karenanya, berperan serta dalam pross pengkokretisasian hukum. (W. Friedmann, Teori Filsafat Hukum, Telaah Kritis atas Teori-Teori Hukum (Susunan I), Penerjemah, Muhammad Arifin. Judul Asli : Legal Theory, Jakarta Utara: Rajawali Pers, 1990, h. 176.) 
Susunan hierarkis pengaturan perangkat desa di Indonesia seperti tergambar pada Bagan III, susunannya bersifat mutlak, tidak bisa ditukar, karena ia terkait dengan kuatnya daya laku dan daya ikat. ${ }^{21}$ Peraturan yang disebutkan pada urutan yang lebih tinggi berarti berkedudukan lebih kuat dan harus menjadi sumber dari peraturan yang ada di bawahnya, begitu seterusnya. Mengingat hal tersebut, tidak boleh ada satu peraturan perundang-undangan yang isinya, baik seluruhnya maupun sebagian, bertentangan dengan peraturan perundang-undangan yang lebih tinggi. Kalau ada yang bertentangan dengan peraturan yang lebih tinggi, maka dinyatakan batal (extunc) atau dibatalkan (exnunc).22 Paradigma (sudut pandang) tersebut di ataslah yang peneliti gunakan dalam penelitian ini. ${ }^{23}$

Berdasarkan pengaturan pengangkatan perangkat desa di Kabupaten Blitar pasca Putusan MK No. 128/PUU-XIII/2015 sebagaimana tergambar dalam Bagan III, Pemerintah Desa adalah Kepala Desa atau yang disebut dengan nama lain dibantu perangkat Desa atau yang disebut dengan nama lain sebagai unsur penyelenggara Pemerintahan Desa. ${ }^{24}$ Dalam melaksanakan tugas, Kepala Desa salah satunya berwenang mengangkat dan memberhentikan perangkat Desa. ${ }^{25}$ Perangkat desa bukan dipilih oleh kepala desa, ${ }^{26}$ melainkan diangkat oleh kepala desa atas rekomendasi Camat dengan mempertimbangkan nilai ujian dan wawancara bakal calon perangkat desa dalam mekanisme penyeleksian perangkat desa. Diksi antara "dipilih" dan "diangkat" oleh Kepala Desa sangat berbeda. Kepala Desa tidak memiliki kewenangan untuk memilih

${ }^{21}$ Ingat Pasal 7 UU No. 12 Tahun 2011 tentang Pembentukan Peraturan PerundangUndangan, hierarki tata hukum di Indonesia terdiri atas tujuh tingkatan yakni (1) UUD NRI 1945, (2) Ketetapan MPR(S) (yang masih berlaku berdasar Tap MPR No. I/MPR/2003), (3) UU/Perppu, (4) Peraturan Pemerintah, (5) Peraturan Presiden, (6) Peraturan Daerah Provinsi, (7) Peraturan Daerah Kabupaten/Kota.

${ }^{22}$ Baca Moh. Mahfud MD, "Pancasila sebagai Pijakan Politik dan Ketatanegaraan", dalam Al Khanif dkk, Pancasila dalam Pusaran Globalisasi, Yogyakarta: LkiS, 2017, h. 9.

23 Paradigma adalah "suatu pangkal(an) atau pola berpikir yang akan mensyarati kepahaman interpretatif seseorang secara individual atau sekelompok orang secara kolektif pada seluruh gugus pengetahuan berikut teori-teori yang dikuasainya". (Kesimpulan peneliti setelah membaca dan memahami tulisan Soetandyo Wignjosoebroto tentang Teori, Konsep dan Paradigma dalam Kajian tentang Manusia, Masyarakat dan Hukumnya. Baca pula Anik Iftitah, "Pancasila Versus Globalisasi: Antara Konfrontasi dan Harmonisasi?", dalam dalam Al Khanif dkk, Pancasila dalam Pusaran Globalisasi, Yogyakarta: LkiS, 2017, h. 35.)

${ }^{24}$ Lihat Pasal 1 angka (3) UU Desa junctis Pasal 25 UU Desa, Pasal 1 ayat 3 PP 43/2014, Pasal 1 ayat 3 Permendagri 67/2017, Pasal 1 angka 8 Perda Kab. Blitar 6/2016, dan Pasal 1 angka 7 Peraturan Bupati Blitar Nomor 27 Tahun 2017.

${ }^{25}$ Lihat Pasal 26 ayat (2) UU Desa juncto Pasal 5 ayat 2 huruf b Perda Kab. Blitar 6/2016.

26 Lihat Made Ayu Trisnawati, Putu Gede Arya Sumerthayas, Pengangkatan dan Pemberhentian Perangkat Desa di Bandung, Program Kekhususan Hukum Pemerintahan Fakultas Hukum Universitas Udayana, h. https://ojs.unud.ac.id/index.php/Kerthanegara/article/view/29572/18268, diakses pada 8 Februari 2019. 
perangkat desa, kewenangannya adalah mengangkat perangkat desa berdasarkan hasil penyeleksian perangkat desa.

Perangkat Desa adalah unsur staf yang membantu kepala Desa dalam penyusunan kebijakan dan koordinasi yang diwadahi dalam sekretariat Desa, dan unsur pendukung tugas kepala Desa dalam pelaksanaan kebijakan yang diwadahi dalam bentuk pelaksana teknis dan unsur kewilayahan. ${ }^{27}$ Perangkat Desa terdiri atas sekretariat Desa, pelaksana kewilayahan, dan pelaksana teknis. ${ }^{28}$ Perangkat Desa berkedudukan sebagai unsur pembantu kepala Desa. ${ }^{29}$ Perangkat Desa bertugas membantu Kepala Desa dalam melaksanakan tugas dan wewenangnya, diangkat oleh Kepala Desa setelah dikonsultasikan dengan Camat atas nama Bupati/Walikota, dan bertanggung jawab kepada Kepala Desa. ${ }^{30}$ Berdasarkan UU Desa, perangkat Desa diangkat dari warga Desa yang memenuhi persyaratan sebagai berikut:

a. berpendidikan paling rendah sekolah menengah umum atau yang sederajat;

b. berusia 20 (dua puluh) tahun sampai dengan 42 (empat puluh dua) tahun;

c. terdaftar sebagai penduduk Desa dan bertempat tinggal di Desa paling kurang 1 (satu)

tahun sebelum pendaftaran ("pasca Putusan Mahkamah Konstitusi dalam perkara

Nomor 128/PUU-XIII/2015. Ketentuan Pasal 50 huruf c UU Desa ini dinyatakan bertentangan dengan Undang-Undang Dasar Negara Republik Indonesia Tahun 1945 dan tidak mempunyai kekuatan hukum mengikat"); dan

d. syarat lain yang ditentukan dalam peraturan daerah kabupaten/kota.

Persyararatan Perangkat Desa diangkat dari warga Desa yang memenuhi persyaratan terdaftar sebagai penduduk Desa dan bertempat tinggal di Desa paling kurang 1 (satu) tahun sebelum pendaftaran, tidak memberikan kesempatan yang sama dan diskriminatif, dapat merugikan hak konstitusional WNI yang secara nyata dijamin haknya untuk mendapatkan perlindungan dan kesempatan yang sama yang sama tidak diskriminatif dalam pemerintahan tanpa terkecuali, bertentangan dengan Pasal $28 \mathrm{H}$ ayat (2) UUD NRI 1945, dimana setiap orang di Indonesia berhak mendapat kemudahan dan perlakuan khusus untuk memperoleh kesempatan dan manfaat yang sama guna mencapai persamaan dan keadilan.

Persyararatan Perangkat Desa diangkat dari warga Desa yang memenuhi persyaratan terdaftar sebagai penduduk Desa dan bertempat tinggal di Desa paling kurang 1 (satu) tahun sebelum pendaftaran, menjadi dasar kewenangan bagi Pemerintah Daerah di atasnya (Camat/Bupati/Walikota) melalui Panitia Penyelenggara Pemilihan Kepala Desa, untuk tidak menerima calon perangkat desa yang tidak/belum terdaftar sebagai penduduk dan bertempat tinggal di desa setempat paling kurang 1 (satu) tahun sebelum pendaftaran, menjadikan WNI yang ingin berpartisipasi membangun desa, terhalang untuk bekerja dengan perlakuan yang adil sebagai Perangkat Desa, karena ada pembatasan dan pengkebiran hak-hak konstitusional. Pasca Putusan MK Nomor 128/PUU-XIII/2015, maka sudah tidak ada dasar kewenangan bagi

${ }^{27}$ Lihat Pasal 1 ayat 5 Permendagri 67/2017 jo Pasal 1 ayat 12 Perbub Blitar 27/2017.

${ }^{28}$ Lihat Pasal 48 UU Desa junctis Pasal 61 PP 43/2014, Pasal 13 Perda 6/2016.

29 Pasal 61 PP 43/2014.

30 Pasal 49 UU Desa. 
Camat/Bupati/Walikota untuk tidak menerima calon perangkat desa terseleksi dari luar desa setempat.

Namun sayangnya, implikasi hukum Putusan MK tersebut, tidak eksplisit tertulis dalam Peraturan Pemerintah Republik Indonesia Nomor 47 Tahun 2015 tentang Perubahan Atas Peraturan Pemerintah Nomor 43 Tahun 2014 tentang Peraturan Pelaksanaan Undang-Undang Nomor 6 Tahun 2014 tentang Desa. Dalam PP 47/2015 jo PP 43/2014, persyaratan perangkat desa terdaftar sebagai penduduk Desa dan bertempat tinggal di Desa paling kurang 1 (satu) tahun sebelum pendaftaran, tidak dihapus. ${ }^{31}$ Inilah salah satu disharmonisasi dalam pengaturan pengangkatan perangkat desa di Indonesia. PP 47/2015 jo PP 43/2014 menjadi salah satu dasar yuridis Peraturan Menteri Dalam Negeri Republik Indonesia Nomor 67 Tahun 2017 tentang Perubahan Atas Peraturan Menteri Dalam Negeri Nomor 83 tahun 2015 tentang Pengangkatan dan Pemberhentian Perangkat Desa. Di satu sisi substansi Permendagri 67/2017 telah sesuai dengan amar Putusan Nomor 128/PUU-XIII/2015, namun di sisi yang lain, Permendagri ini mendasarkan pada PP yang belum sesuai dengan putusan MK tersebut. Perhatikan Bagan IV berikut, agar lebih gamblang.

Bagan IV. Disharmoni UU Desa, PP 47/2017, dan Permendagri 67/2017 Pasca Putusan MK 128/PUU-XIII/2015

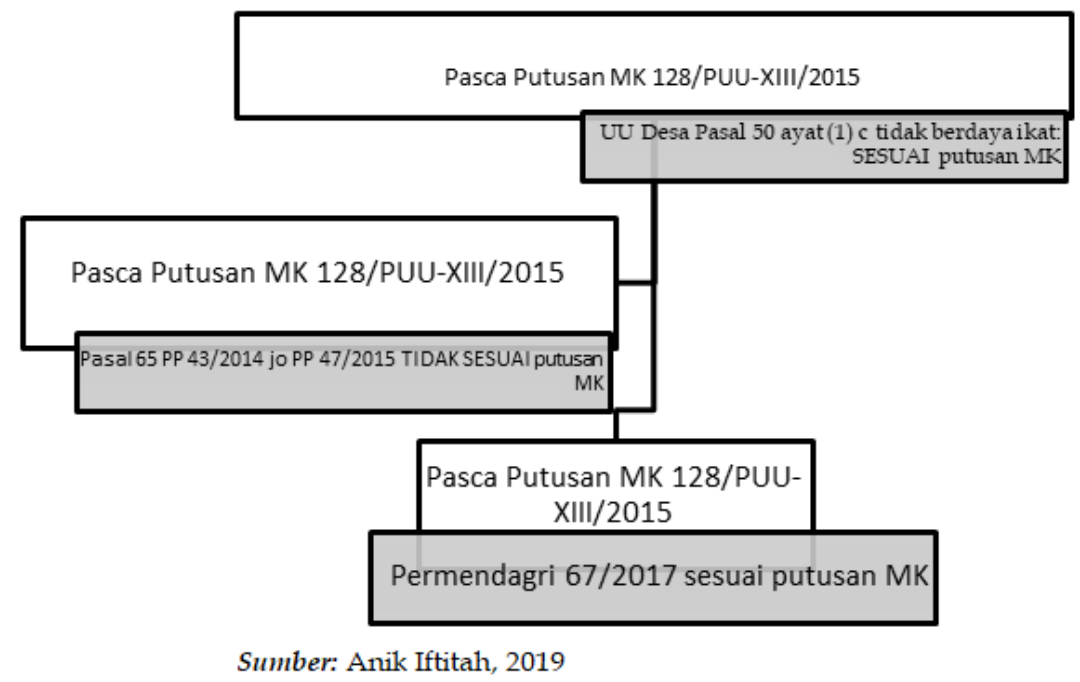

Perangkat Desa diangkat oleh kepala Desa dari warga Desa yang telah memenuhi persyaratan umum dan khusus, yaitu:

1). Persyaratan umum:

a. berpendidikan paling rendah sekolah menengah umum atau yang sederajat;

b. berusia 20 (dua puluh) tahun sampai dengan 42 (empat puluh dua) tahun;

c. dihapus;

d. memenuhi kelengkapan persyaratan administrasi ${ }^{32}$ yang terdiri atas:

a. Kartu Tanda Penduduk atau surat keterangan tanda penduduk;

${ }^{31}$ Lihat Pasal 65 PP 43/2014 jo PP 47/2015.

32 Pasal 2 Permendagri 67/2017. 
b. surat pernyataan bertakwa kepada Tuhan Yang Maha Esa yang dibuat oleh yang bersangkutan di atas kertas bermaterai;

c. surat pernyataan memegang teguh dan mengamalkan Pancasila, Undang-Undang Dasar Negara Republik Indonesia Tahun 1945, mempertahankan dan memelihara keutuhan Negara Kesatuan Republik Indonesia dan Bhinneka Tunggal Ika, yang dibuat oleh yang bersangkutan diatas kertas segel atau bermaterai cukup;

d. ijazah pendidikan dari tingkat dasar sampai dengan ijazah terakhir yang dilegalisasi oleh pejabat berwenang atau surat pernyataan dari pejabat yang berwenang;

e. akte kelahiran atau surat keterangan kenal lahir;

f. surat keterangan berbadan sehat dari puskesmas atau petugas kesehatan yang berwenang; dan

g. surat permohonan menjadi perangkat Desa yang dibuat oleh yang bersangkutan di atas kertas segel atau bermaterai cukup bagi perangkat Desa yang diproses melalui penjaringan dan penyaringan. ${ }^{33}$ Atau lebih detailnya tertulis dalam Perbub Blitar Nomor 9/2017 sebagai berikut:

a. surat pernyataan bertakwa kepada Tuhan Yang Maha Esa yang dibuat oleh yang bersangkutan di atas kertas bermaterai;

b. surat pernyataan memegang teguh dan mengamalkan Pancasila, Undang-Undang Dasar Negara Republik Indonesia Tahun 1945, mempertahankan dan memelihara keutuhan Negara Kesatuan Republik Indonesia dan Bhinneka Tunggal Ika, yang dibuat oleh yang bersangkutan diatas kertas segel atau bermaterai cukup;

c. surat pernyataan bersedia ditempatkan dalam jabatan apapun dalam struktur Pemerintah Desa;

d. fotokopi Kartu Tanda Penduduk atau Surat Keterangan dilegalisir oleh Dispendukcapil;

e. fotokopi Ijazah pendidikan dari tingkat dasar sampai dengan ijazah terakhir yang dilegalisasi oleh pejabat berwenang atau surat keterangan dari pejabat yang berwenang;

f. fotokopi Akte Kelahiran dilegalisir oleh Dispendukcapil;

g. surat pernyataan tidak pernah dijatuhi pidana penjara berdasarkan putusan Pengadilan yang telah mempunyai kekuatan hukum tetap karena melakukan tindakan pidana penjara paling singkat 2 (dua) tahun dan atau bukan sebagai pelaku kejahatan yang berulang-ulang;

h. Surat Keterangan Catatan kepolisian dari Kepolisian setempat;

i. surat Keterangan berbadan sehat dari Rumah Sakit Umum Daerah atau dari Puskesmas setempat;

j. surat keterangan bebas narkoba dari Badan Narkotika Kabupaten;

k. surat ijin tertulis dari pejabat yang berwenang bagi pendaftar yang berasal dari ASN, TNI dan Polri.

1. surat pernyataan sanggup bertempat tinggal di Desa yang bersangkutan dari calon Perangkat Desa diatas kertas bermaterai;

${ }^{33}$ Lihat Pasal 3 Permendagri 67/2017. 
m. daftar riwayat hidup;

Surat permohonan Bakal Calon Perangkat Desa ditulis diatas kertas bermaterai cukup diajukan kepada Kepala Desa melalui Panitia Seleksi Perangkat Desa dengan dilengkapi persyaratan administrasi. ${ }^{34}$

2). Persyaratan Khusus perangkat desa adalah mempunyai pengetahuan dan ketrampilan sesuai dengan yang dibutuhkan, diantaranya pengetahuan dan ketrampilan dalam bidang:
a. administrasi perkantoran;
b. administrasi keuangan;
c. perencanaan;
d. teknologi informasi;
e. hubungan kemasyarakatan; dan
f. bidang lainnya sesuai kebutuhan desa. ${ }^{35}$

Pengangkatan perangkat Desa dilaksanakan dengan mekanisme sebagai berikut:

a. kepala Desa melakukan penjaringan dan penyaringan atau seleksi calon perangkat Desa;

b. kepala Desa melakukan konsultasi dengan camat atau sebutan lain mengenai pengangkatan perangkat Desa;

c. camat atau sebutan lain memberikan rekomendasi tertulis yang memuat mengenai calon perangkat Desa yang telah dikonsultasikan dengan kepala Desa; dan

d. rekomendasi tertulis camat atau sebutan lain dijadikan dasar oleh kepala Desa dalam pengangkatan perangkat Desa dengan keputusan kepala Desa. ${ }^{36}$

Pengangkatan Perangkat Desa dilaksanakan melalui mekanisme sebagai berikut:

a. Kepala Desa membentuk Tim yang terdiri dari seorang ketua, seorang sekretaris dan minimal seorang anggota;

b. Kepala Desa melakukan penjaringan dan penyaringan calon Perangkat Desa yang dilakukan oleh Tim;

c. Pelaksanaan penjaringan dan penyaringan bakal calon Perangkat Desa dilaksanakan paling lama 2 (dua) bulan setelah jabatan perangkat desa kosong atau diberhentikan;

d. Hasil penjaringan dan penyaringan bakal calon Perangkat Desa sekurang-kurangnya 2 (dua) orang calon dikonsultasikan oleh Kepala Desa kepada Camat;

e. Camat memberikan rekomendasi tertulis terhadap calon Perangkat Desa selambatlambatnya 7 (tujuh) hari kerja;

f. Rekomendasi yang diberikan Camat berupa persetujuan atau penolakan berdasarkan persyaratan yang ditentukan;

g. Dalam hal Camat memberikan persetujuan, Kepala Desa menerbitkan Keputusan Kepala Desa tentang Pengangkatan Perangkat Desa; dan

h. Dalam hal rekomendasi Camat berisi penolakan, Kepala Desa melakukan penjaringan dan penyaringan kembali calon Perangkat Desa. ${ }^{37}$

\footnotetext{
${ }^{34}$ Lihat Pasal 3 Perbub Blitar 9/2017.

35 Pasal 77 Perda Kab. Blitar 6/2016 jo Pasal 2 Perbub Blitar 27/2017.

36 Lihat Pasal 66 PP 43/2014 jo PP 47/2015.

${ }_{37}$ Pasal 4 Permendagri 83/2015 jo Pasal 79 Perda Kab. Blitar 6/2016.
} 
Tim Penjaringan dan Penyaringan Perangkat Desa selanjutnya disebut Panitia Seleksi Perangkat Desa adalah tim yang dibentuk dan ditetapkan oleh Kepala Desa bertugas untuk melaksanakan proses penjaringan dan penyaringan atau seleksi Perangkat Desa. ${ }^{38}$ Penjaringan adalah suatu upaya yang dilaksanakan oleh Panitia Seleksi Perangkat Desa untuk mendapatkan Bakal Calon Perangkat Desa. ${ }^{39}$ Sedangkan penyaringan adalah seleksi yang diselenggarakan oleh Panitia Seleksi Perangkat Desa baik dari segi administrasi, ujian tertulis dan wawancara. ${ }^{40}$ Bakal calon perangkat desa adalah Warga Negara Indonesia yang mencalonkan diri sebagai calon Perangkat Desa.41 Calon Perangkat Desa adalah orang yang ditetapkan oleh Kepala Desa telah memenuhi persyaratan dari hasil proses penjaringan dan penyaringan atau seleksi yang dilaksanakan oleh Panitia Seleksi Perangkat Desa, untuk mendapatkan rekomendasi camat. ${ }^{42}$

Penyaringan dilaksanakan secara jujur, adil dan transparan, meliputi kegiatan :

a. pemeriksaan kelengkapan persyaratan administrasi;

b. ujian tertulis materi pengetahuan umum yang meliputi:

a. Pancasila dan Undang-Undang Dasar Negara Republik Indonesia Tahun 1945;

b. Dihapus;

c. pengetahuan yang berkaitan dengan Pemerintahan Desa;

d. pengetahuan tentang disiplin ilmu yang dibutuhkan oleh Pemerintah Desa yang bersangkutan;

e. pengetahuan tentang pengenalan wilayah desa yang bersangkutan.

dan materi pengetahuan khusus tentang Pemerintahan Desa tentang :

a. administrasi perkantoran;

b. administrasi keuangan;

c. administrasi pemerintahan;

d. perencanaan ;

e. teknologi informasi;

f. peraturan perundang-undangan;

g. hubungan masyarakat. ;

c. wawancara. ${ }^{43}$

Pemeriksaan hasil ujian tertulis terhadap bakal calon perangkat desa di atas dilakukan Panitia Seleksi pada hari yang sama dengan saat ujian dilaksanakan, dan hasil penelitian ujian dituangkan dalam Berita Acara untuk disampaikan kepada Kepala Desa dan diumumkan kepada masyarakat. ${ }^{44}$ Mekanisme penetapan calon perangkat desa adalah sebagai berikut. Panitia seleksi menyampaikan Berita Acara hasil penjaringan dan penyaringan kepada Kepala Desa paling lambat 3 (tiga) hari setelah pelaksanaan ujian selesai. Paling sedikit 2 (dua) bakal calon yang memperoleh nilai tertinggi ditetapkan

\footnotetext{
38 Perbub Blitar 27/2017 Pasal 1 angka 22.

39 Perbub Blitar 27/2017 Pasal 1 angka 23.

40 Perbub Blitar 27/2017 Pasal 1 angka 24.

${ }^{41}$ Perbub Blitar 27/2017 Pasal 1 angka 25.

42 Perbub Blitar 27/2017 Pasal 1 angka 26.

${ }^{43}$ Lihat Pasal 6 Perbub Blitar 27/2017.

${ }^{44} \mathrm{Idem}$.
} 
sebagai Calon Perangkat Desa untuk diajukan/dikonsultasikan kepada Camat. Pengajuan/konsultasi Kepala Desa kepada Camat disertai Berita Acara hasil penjaringan dan penyaringan dalam waktu paling lama 7 (tujuh) hari sejak pelaksanaan ujian selesai. Camat memberikan rekomendasi dalam bentuk tertulis terhadap Calon yang diajukan Kepala Desa dalam waktu paling lambat 7 (tujuh) hari sejak menerima permohonan/pengajuan. Apabila dalam waktu tersebut di atas Camat tidak memberikan rekomendasi, Camat dianggap menyetujui. Rekomendasi Camat dapat berupa persetujuan atau penolakan berdasarkan persyaratan yang ditentukan dan berpedoman pada :

a. persyaratan umum dan persyaratan khusus;

b. kelengkapan persyaratan administrasi; dan

c. hasil ujian tertulis maupun wawancara.

Apabila rekomendasi Camat berupa persetujuan Kepala Desa menindaklanjuti dalam bentuk Keputusan Kepala Desa tentang Penetapan dan Pengangkatan Perangkat Desa. Dalam hal rekomendasi Camat berupa penolakan Kepala Desa menindaklanjuti dengan melaksanakan penjaringan dan penyaringan bakal calon Perangkat Desa kembali. Jika rekomendasi Camat berisi penolakan sedangkan Kepala Desa tetap menerbitkan Keputusan Kepala Desa tentang penetapan dan pengangkatan Perangkat Desa, keputusan Kepala Desa tersebut dinyatakan batal demi hukum. ${ }^{45}$

Peraturan Bupati Blitar Nomor 9 Tahun 2017 jo Peraturan Bupati Blitar Nomor 27 Tahun 2017 tentang Pedoman Pengangkatan dan Pemberhentian Perangkat Desa sebagai peraturan pedoman pengangkatan Perangkat Desa di wilayah Kabupaten Blitar, ternyata mengandung substansi yang tidak berkepastian hukum. Hal ini dapat dengan mudah dipahami dalam tahap perekomendasian calon perangkat desa yang rawan pertimbangan dan penetapan yang subjektif oleh oknum Kepala Desa dan/atau Camat terkait, mengabaikan proses obyektif penyeleksian bakal calon perangkat desa. Dalam tahap camat harus memberikan rekomendasi dalam bentuk tertulis terhadap calon yang diajukan kepala desa, tidak ada aturan berkepastian yang mengatur bahwa camat harus merekom calon perangkat desa berdasarkan nilai tertinggi hasil ujian tulis dan wawancara seleksi bakal calon perangkat desa. Hal demikian membuka celah praktek permainan subyektifitas pada perekomendasian, penentuan, dan/atau penetapan atas calon perangkat desa final. Implikasi demikian, dapat dengan gamblang dilihat dan dipahami dalam proses penetapan calon perangkat desa di Desa Tlogo, Kabupaten Blitar pada 28 Desember 2017.46

\footnotetext{
45 Lihat Pasal 7 dan 8 Perbub Blitar 9/2017.

${ }^{46}$ Baca http:/ / www.blitartimes.com/baca/164303/20180101/135257/kades-punya-hakprerogatif-seleksi-perangkat-desa-tlogo-kanigoro-disebut-sarat-kkn/, diakses pada Januari 2019.
} 
Gambar I. Daftar Nilai Hasil Tes Tulis dan Wawancara

Seleksi Calon Perangkat Desa Tlogo, Kanigoro, Blitar

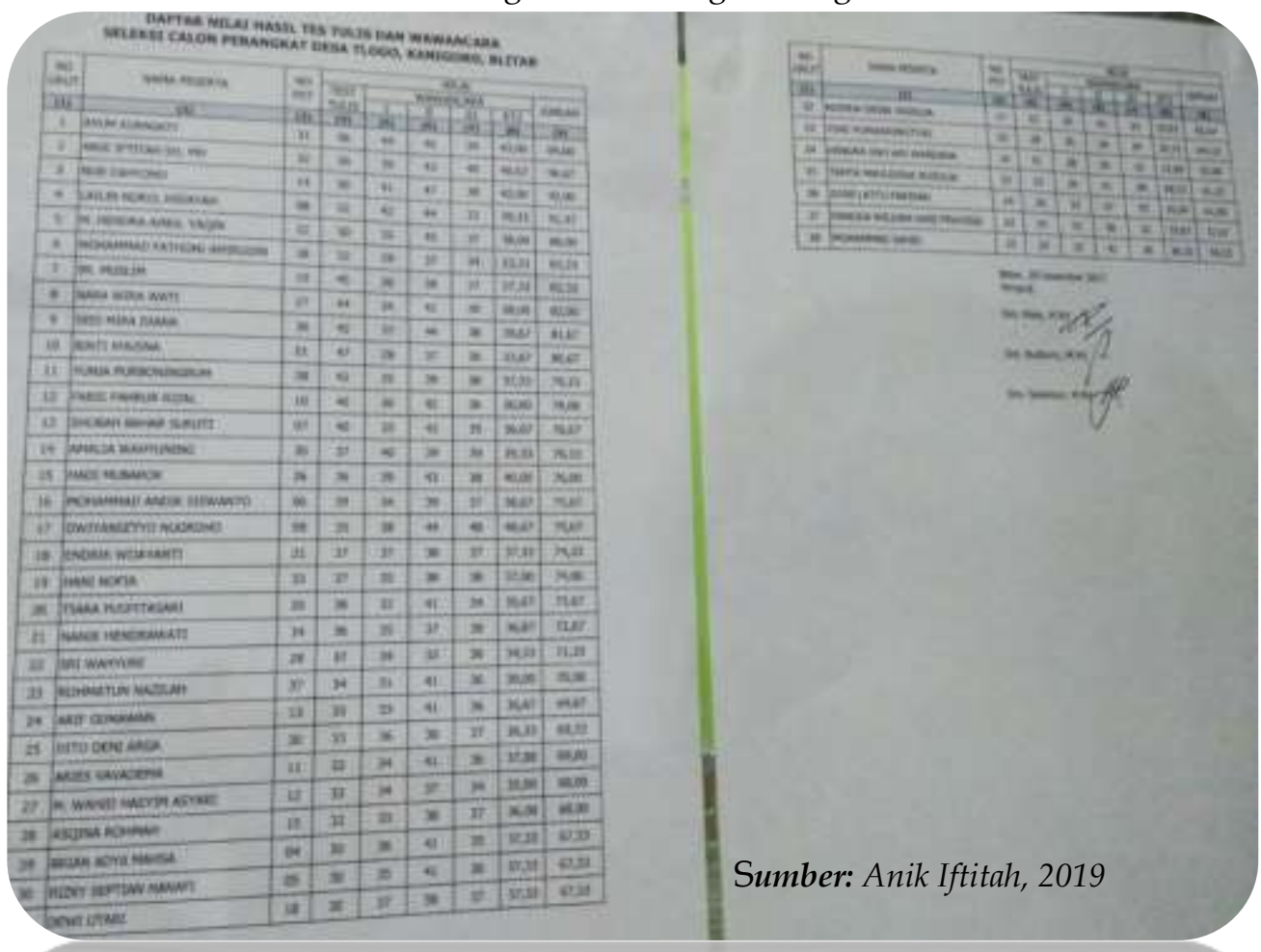

Dari hasil tes tulis dan wawancara seleksi calon perangkat desa seperti tergambar pada Gambar I, maka ditetapkanlah bakal calon perangkat desa berdasarkan nilai tertinggi sebanyak $2 \times$ dari jumlah kuota perangkat desa yang diperlukan. Jika ada 3 kuota calon perangkat desa, maka ditetapkanlah bakal calon (bacalon) perangkat desa sebanyak 2x $3=6$ bacalon, seperti tergambar pada Gambar II.

Gambar II. Berita Acara Penetapan Bakal Calon Perangkat Desa

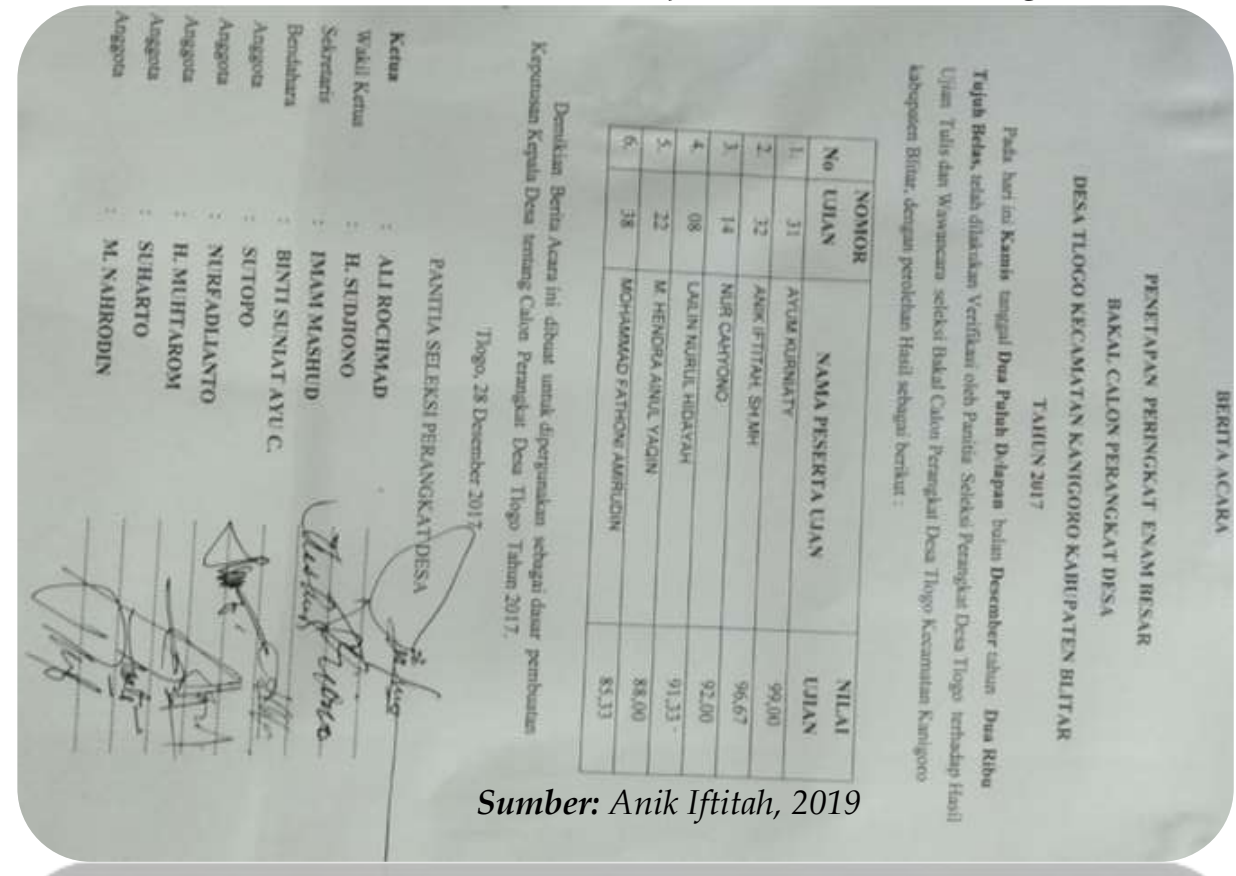


Dari 6 bacalon seperti tertulis dalam Gambar II, maka kepala desa mengajukan permohonan rekomendasi calon perangkat desa kepada camat, sebagaimana tergambar dalam Gambar IV.

Gambar IV. Permohonan Rekomendasi Calon Perangkat Desa dari Kepala Desa kepada

\section{Camat}

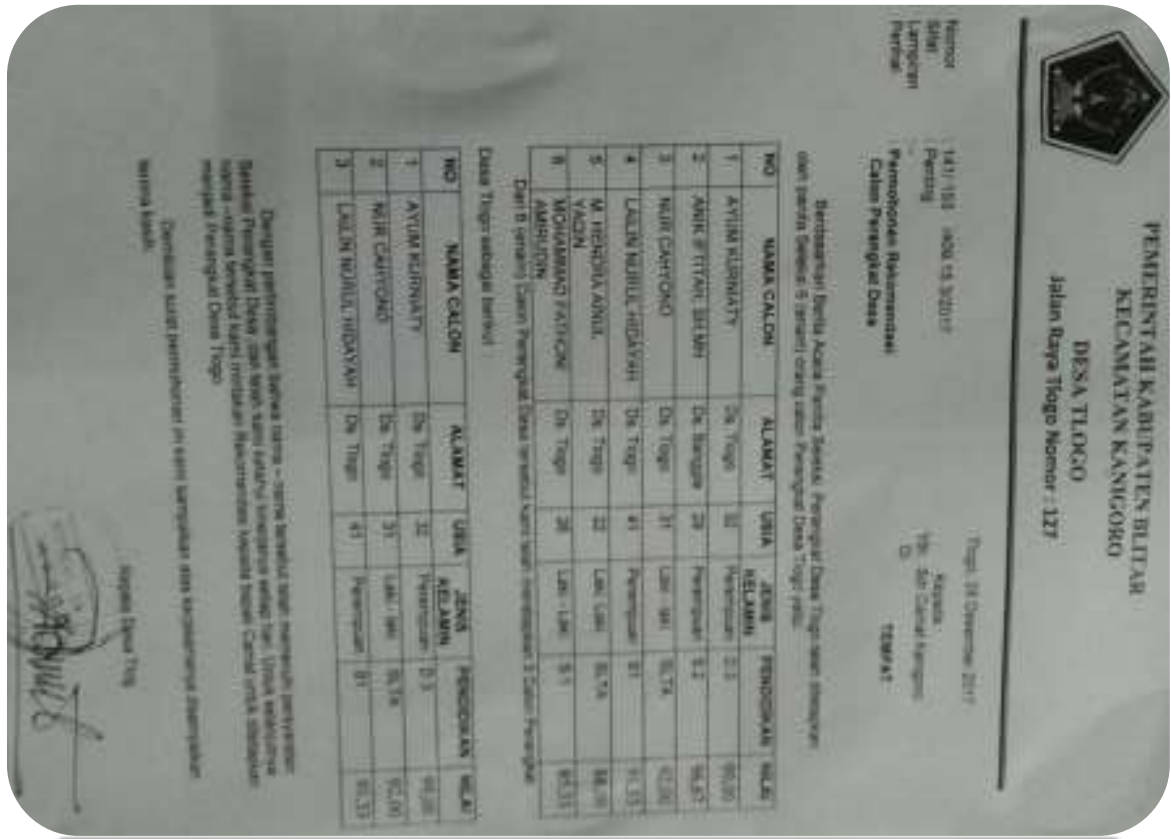

Sumber: Anik Iftitah, 2019

Selanjutnya, Camat memberikan rekomendasi pengangkatan perangkat desa, sebagaimana yang tergambar dalam Gambar V.

Gambar V. Rekomendasi Pengangkatan Perangkat Desa oleh Camat kepada Kepala Desa

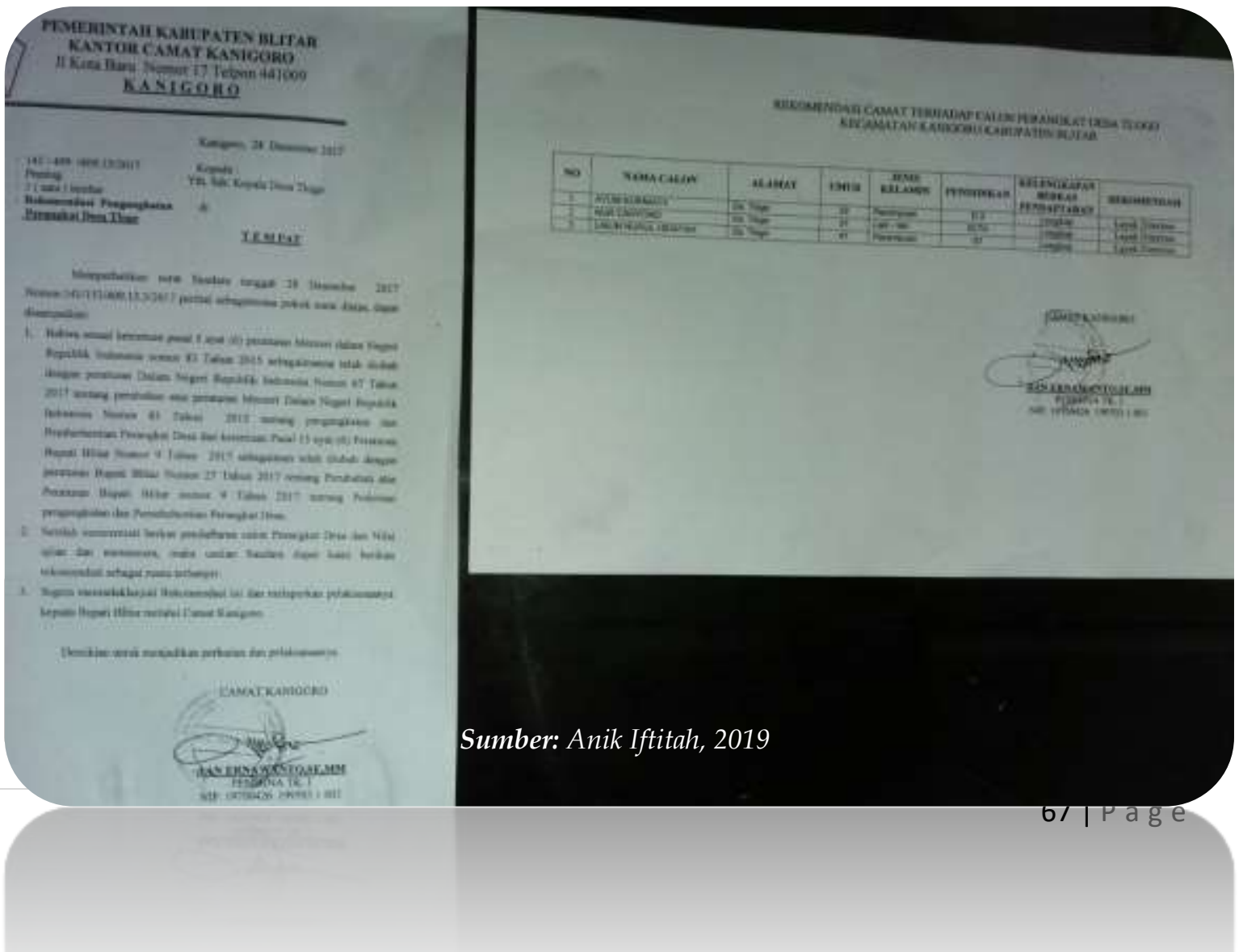


Dari Gambar IV dan V, tergambar jelas bagaimana pengabaian segala proses seleksi perangkat desa. Mengabaikan hasil pemenuhan persyaratan umum dan persyaratan khusus; kelengkapan persyaratan administrasi; dan mengabaikan hasil ujian tertulis maupun wawancara. Terbukti jelas bagaimana kandidat nomor 2 nilai tertinggi diabaikan tanpa alasan jelas berlandaskan hukum dan berkepastian hukum. Yang nampak adalah alasan pertimbangan berdasar unsur daerah asal bacalon. Calon perangkat desa yang mendapatkan rekomendasi pengangkatan dari Camat kepada Kepala Desa, berasal dari desa setempat, sedang bacalon tertinggi nomor 2, berasal dari luar daerah setempat. Hal demikian jelas membuktikan adanya praktek pengangkatan perangkat desa yang tidak memberikan kesempatan yang sama dan diskriminatif, dapat merugikan hak konstitusional WNI terkait yang secara nyata dijamin haknya untuk mendapatkan perlindungan dan kesempatan yang sama, tidak diskriminatif dalam pemerintahan tanpa terkecuali. Tegasnya, hal demikian bertentangan dengan Pasal $28 \mathrm{H}$ ayat (2) UUD NRI 1945, dimana setiap orang di Indonesia berhak mendapat kemudahan dan perlakuan khusus untuk memperoleh kesempatan dan manfaat yang sama guna mencapai persamaan dan keadilan.

\section{PENUTUP}

Kepala Desa (stuktur hukum) merupakan komponen paling vital dalam terwujud tidaknya cita peraturan pengangkatan perangkat desa di Kabupaten Blitar yang konstitusional. Komponen struktural dalam sistem hukum, merupakan komponen yang paling vital, dalam pelaksanaan hukum. Kata Prof. Sciler, tergantung manusianya. Bahkan, kata filosof Trafene "berilah aku pelaksana hukum yang bagus, sekalipun substansi hukumnya jelek". ${ }^{47}$

Kepala Desa dan Camat sebagai aparat pelaksana hukum pengangkatan perangkat desa, harus bertindak untuk mengontrol pemikiran dan langkah-langkah agar selalu terpelihara tidak melakukan perbuatan yang melanggar hukum, sebagaimana fungsi hukum sebagai as a tool of social control, sehingga terwujudlah fungsi hukum sebagai as a tool of social engineering, yaitu menjadi kekuatan untuk mengubah masyarakat ("change agent"), yang menciptakan kondisi sosial yang baru, yaitu dengan peraturan-peraturan hukum yang diciptakan dan dilaksanakan, terjadilah social engineering, terjadilah sosial menuju keadaan hidup yang lebih baik. Kepala Desa dan Camat sebagai aparat pelaksana hukum pengangkatan perangkat desa, tidak dapat berbuat semauanya diluar apa yang telah digariskan dalam ketentuan-ketentuan perundang-undangan (ultra vires) ${ }^{4} 8$

47 Prof. Dr. Koesno Adi, SH., MS, Kuliah Filsafat Hukum Semester 1 Tahun Akademik 2015/2016 di Magister Ilmu Hukum Universitas Islam Kadiri Kediri.

48 SF Marbun dkk, Dimensi-Dimensi Pemikiran Hukum Administrasi Negara, Yogyakarta : UII Press, 2001, h.370. 


\section{DAFTAR PUSTAKA}

\section{Buku}

Alfarezi, Salman, Pengangkatan Perangkat Desa dalam Pandangan Hukum Islam dan Hukum Positif (Studi di Pekon Negeriagung, Kec. Talang Padang Kab. Tanggamus), Skripsi, Tidak Diterbitkan, Fakultas Ilmu Komunikasi, Universitas Harapan Jaya: Bandung.

Friedmann, W., Teori Filsafat Hukum, Telaah Kritis atas Teori-Teori Hukum (Susunan I), Penerjemah, Muhammad Arifin. Judul Asli : Legal Theory, Jakarta Utara: Rajawali Pers, 1990.

Ibrahim, Johnny, Teori dan Metode Penelitian Hukum Normatif, Cet. 4, Malang: Bayumedia Publishing, 2011.

Lestari, Fadhilah, “Analisis Putusan Mahkamah Konstitusi Nomor 128/PUU-XIII/2015 terhadap Penghapusan Domisili Calon Kepala Desa dalam Pemilihan Kepala Desa", Tesis, Pascasarjana FH-UII, 2018.

Marbun, SF, dkk, Dimensi-Dimensi Pemikiran Hukum Administrasi Negara, Yogyakarta : UII Press, 2001.

Ramadhani, R.A. Granita, Analisa Aspek Metodologi, FH UI, 2009, h. 57.

Soekanto, Soerjono dan Mamudji, Sri, Penelitian Hukum Normatif, Suatu Tinjauan Singkat, Jakarta: Raja Grafindo Persada, 2011.

Soeno S.H., Ilmu Negara, Yogyakarta: Libeti, 2005.

Wignjosoebroto, Prof. Soetandyo, "Hukum yang Tak Kunjung Tegak: Apa yang Salah dengan Kerja Penegakan Hukum di Negeri Ini?" dalam Dinal Fedrian dkk, Dialektika Pembaharuan Sistem Hukum Indonesia, Jakarta: Komisi Yudisial Republik Indonesia, 2012.

Kontributor Buku

Iftitah, Anik, "Pancasila Versus Globalisasi: Antara Konfrontasi dan Harmonisasi?", dalam dalam Al Khanif dkk, Pancasila dalam Pusaran Globalisasi, Yogyakarta: LkiS, 2017.

Mahfud MD, Moh., "Pancasila sebagai Pijakan Politik dan Ketatanegaraan", dalam Al Khanif dkk, Pancasila dalam Pusaran Globalisasi, Yogyakarta: LkiS, 2017.

\section{Jurnal}

Kusnadi, Agus, "Perkembangan Politik Hukum Pemerintahan Desa Menurut UndangUndang Nomor 32 Tahun 2004 tentang Pemerintahan Daerah dan Undang-Undang Nomor 6 Tahun 2014 tentang Desa", Padjadjaran Jurnal Ilmu Hukum, Volume 2 Nomor 3 Tahun 2015.

Muslim, Nur'aini dan Nasution, Irwan, “Kinerja Aparat Desa dalam Penyelenggaraan Pemerintahan di desa Pantai Labu Pekan", Jurnal Ilmu Pemerintahan dan Sosial Politik UMA, 2 (2) (2014).

Sonata, Depri Liber, "Metode Penelitian Hukum Normatif dan Empiris: Karakteristik Khas dari Metode Meneliti Hukum", Fiat Justisia Jurnal Ilmu Hukum, Volume 8 No. 1, Januari-Maret 2014. 
Trisnawati, Made Ayu; Sumerthayas, Putu Gede Arya; Pengangkatan dan Pemberhentian Perangkat Desa di Bandung, Program Kekhususan Hukum Pemerintahan Fakultas Hukum Universitas Udayana, https:// ojs.unud.ac.id/index.php/Kerthanegara/article/view/29572/18268, diakses pada 8 Februari 2019.

\section{Internet/media online}

http://www.blitartimes.com/baca/164303/20180101/135257/kades-punya-hakprerogatif-seleksi-perangkat-desa-tlogo-kanigoro-disebut-sarat-kkn/, diakses pada Januari 2019.

Wignjosoebroto, Prof. Soetandyo, Teori, Konsep dan Paradigma dalam Kajian tentang Manusia, Masyarakat dan Hukumnya, https:// www.academia.edu/35964020/TENTANG_TEORI_KONSEP_DAN_PARA DIGMA_DALAM_KAJIAN_TENTANG_MANUSIA_MASYARAKAT_DAN_HUKU MNYA_oleh_Soetandyo_Wignjosoebroto.

\section{Peraturan Perundang-undangan}

Undang-Undang Republik Indonesia Nomor 6 Tahun 2014 tentang Desa.

Undang-Undang Republik Indonesia Nomor. 12 Tahun 2011 tentang Pembentukan Peraturan Perundang-Undangan

Peraturan Pemerintah Republik Indonesia Nomor 47 Tahun 2015 tentang Perubahan Atas Peraturan Pemerintah Nomor 43 Tahun 2014 tentang Peraturan Pelaksanaan Undang-Undang Nomor 6 Tahun 2014 tentang Desa.

Peraturan Menteri Dalam Negeri Republik Indonesia Nomor 67 Tahun 2017 tentang Perubahan Atas Peraturan Menteri Dalam Negeri Nomor 83 Tahun 2015 tentang Pengangkatan dan Pemberhentian Perangkat Desa.

Lampiran Peraturan Menteri Dalam Negeri Republik Indonesia Nomor 84 Tahun 2015 tentang Susunan Organisasi dan Tata Kerja Pemerintah Desa.

Peraturan Daerah Kabupaten Blitar Nomor 6 Tahun 2016 tentang Pemerintahan Desa.

Peraturan Bupati Blitar Nomor 27 Tahun 2017 tentang Perubahan Atas Peraturan Bupati Blitar Nomor 9 Tahun 2017 tentang Pedoman Pengangkatan dan Pemberhentian Perangkat Desa.

\section{Putusan Pengadilan}

Putusan Mahkamah Konstitusi Nomor 128/PUU-XIII/2015 tentang Pengujian UndangUndang Nomor 6 Tahun 2014 tentang Desa terhadap Undang-Undang Dasar Negara Republik Indonesia Tahun 1945, 23 Agustus 2016. 